\title{
CHALLENGES FOR THE LABOR MARKET: 2 COMPLEMENTARY APPROACHES TO PREMATURE CESSATION OF OCCUPATIONAL ACTIVITY
}

\section{ALEKSANDRA PIŁAT ${ }^{1}$, MICHAŁ WILGA ${ }^{1}$, MATILDE LEONARDI ${ }^{2}$, ANASTASIA VLACHOU ${ }^{3}$, and BEATA TOBIASZ-ADAMCZYK ${ }^{1}$}

\author{
${ }^{1}$ Jagiellonian University Medical College, Kraków, Poland \\ Department of Medical Sociology \\ ${ }^{2}$ Fondazione IRRCS, Milan, Italy \\ Neurological Institute Carlo Besta \\ ${ }^{3}$ University of Thessaly, Volos, Greece \\ Department of Special Education
}

\begin{abstract}
Objectives: Current demographic trends, such as society aging, the spreading of chronic diseases, as well as early retirement choices, lead to the dwindling labor market population. Taking into consideration the foregoing tendencies and their consequences, the issue of the shrinking labor force resources seems to be the most important challenge for the labor market. In response to it, this paper identifies individual and institutional causes of withdrawal from the labor market, and explores the views of Polish stakeholders on existing strategies for the occupational re-integration of persons with chronic diseases (PwCDs). Material and Methods: Polish results of 2 European projects: "Participation to Healthy Workplaces and Inclusive Strategies in the Work Sector" (the PATHWAYS project) and "The Collaborative Research on Aging in Europe" (COURAGE in Europe) complemented each other. The cross-sectional population data and data from stakeholders' interviews were used. Results: The authors identified several causes which could encourage people to withdraw from the labor market before attaining the official retirement age at 3 different levels: individual, occupational, and institutional. Although research has shown that the macro-level situation is crucial to staying occupationally active, in Poland stakeholders have reported the lack of effective coordination in the implementation of policies for the occupational re-integration of PwCDs. Conclusions: A decision to cease work prematurely reflects a combination of many different factors, such as individual determinates, work characteristics, personal convictions, and systemic solutions. The study demonstrated that, despite the awareness of the dwindling resources of labor force, the employment-related challenges faced by PwCDs as well as people who are close to the retirement age remain unaddressed. Int J Occup Med Environ Health. 2019;32(5):695-721
\end{abstract}

Key words:

Poland, chronic disease, older workers, early retirement, early exit from work, labor force

\footnotetext{
Funding: the study was financed from the financial resources for science in 2016-2018, granted for the implementation of an international co-funded project. This study was supported by the European Union's Health Programme (2014-2020) (grant No. 663474 entitled "PATHWAYS: Participation To Healthy Workplaces And inclusive Strategies in the Work Sector," project manager: Matilde Leonardi, Ph.D.) and by the Polish Ministry of Science and Higher Education (grant No. 3649/HP3/16/2017/2, project manager: Prof. Beata Tobiasz-Adamczyk). This study was also supported by the European Community's Seventh Framework Programme (FP7/2007-2013) (grant No. 223071 entitled "The Collaborative Research on Aging in Europe," project manager: Matilde Leonardi, Ph.D.) and by the Polish Ministry of Science and Higher Education (grant No. 1277/7PR/UE/2009/7, project manager: Prof. Beata Tobiasz-Adamczyk).

Received: April 20, 2018. Accepted: July 18, 2019.

Corresponding author: Aleksandra Piłat, Jagiellonian University Medical College, Department of Medical Sociology, Kopernika 7a, 31-034 Kraków, Poland (e-mail: aleksandra.pilat@uj.edu.pl).
} 


\section{INTRODUCTION}

Most European countries have to deal with 2 opposite trends. On the one hand, there is a rise in life expectancy, which includes an increased number of healthy life years (HLY), and improved people's health conditions. On the other hand, by 2030 every second resident of Western Europe will have attained the age of 50, and every fourth will be $>65$ [1]. Those factors are involved especially in the global process of population aging and, as a result, in the dwindling resources of the working age population. It seems that staying longer on the labor market should be the natural consequence of these processes, and many developed countries, in response to this trend, have implemented legislations to raise the official retirement age [2]. Nevertheless, people withdraw from the labor market even before attaining that age, and the early retirement trend seems to be spreading across European countries. It may be, therefore, worth investigating why these opposite trends are observed together and what lies behind this phenomenon.

\section{The concept of early retirement}

Retirement means withdrawal from one's position or occupation, or from active working life, upon attaining the age at which people are entitled to get their retirement pay. The situation in which people withdraw from the labor market, do not seek work, and also consider themselves retired, despite their age being below the official retirement age, is defined as early retirement. To be more precise, the definition of early retirement as used by the Organisation for Economic Co-operation and Development (OECD) is as follows: "a situation when an individual decides to retire earlier and draw the pension benefits earlier than their normal retirement age" [3]. In this paper, the authors focused on the Polish population and, in view of the Polish legal solutions regarding retirement age (65 for men and 60 for women), defined a person on early retirement as a non-working retired man aged 50-64, and a non-working retired woman aged 50-59.
A decision to retire early is one of the most important decisions an individual can make during his or her lifetime: retirement means lower earnings, but more time for yourself. It also marks the beginning of spending the retirement resources accumulated throughout the working life.

There are various approaches to analyzing premature withdrawal from occupational activity, but it is enough to mention 3 of them. The first one is referred to as the disengagement theory which views aging as a natural and acceptable process of withdrawing or disengaging from various social roles, activities, and relationships [4]. This theory shows retirement as an acceptable and expected behavior, so even people who are healthy should withdraw from occupational activity. A theory which encourages people to stay active is the theory developed by Robert J. Havighurst as a response to the disengagement theory of aging. The activity theory of aging assumes that the more active older people are, the better. According to Havighurst, successful aging means upholding, as far and as long as possible, the activities and attitudes of middle age [5]. In this approach, if a person decides to go on retirement, it is very important for him or her to find new activities to replace work. The third theory is the continuity theory which assumes that older adults maintain their activities, lifestyles and relationships of the past [6]. However, all these theories are too generalized to explain transition to retirement [7]. Their evaluation reflects attitudes to aging and retirement in societies, and demonstrates how the concept of retirement has changed over the years.

There are many factors which determine the pension system itself, the social acceptance of retirement decisions, and the early retirement provisions which may accidentally encourage people to retire early [8]. One of these factors is the cultural age deadline - cultural constructions of age at which certain events, e.g., transition to retirement, should occur [9-12]. The society shows its expectations towards the age timetable, i.e., when is the right time to get 
married, have a child, work, and go on retirement. These expectations can influence retirement decisions in 2 ways: by encouraging people to withdraw from the labor market or by keeping them occupationally active as long as possible.

Changes in the retirement age, better workforce organization and working conditions, as well as increased educational and career prospects should keep employees occupationally active as long as possible. Nevertheless, the applicable early retirement provisions have been used so extensively that they have become a distinctive feature of the social security system in all industrialized countries and post-modern societies, including Poland [13]. As a result, the early retirement trend has become very common in most European countries.

Decisions to retire early are clearly visible in Polish statistics. On the one hand, according to the Labour Force Survey (LFS) in Poland, both the activity rate and female participation in the labor market have slightly increased in the last decade. On the other hand, the number of people who are occupationally inactive has also grown. More than one-third of them are of working age (18-59) [14]. Based on the research conducted in Poland, the most common reasons for not working include improving one's education and qualifications, family responsibilities associated with household duties or care-giving, and health conditions (e.g., chronic disease, disability). Retirement, including early retirement, was identified as yet another reason for not working (in $12.5 \%$ of cases). Among women and men aged 55-64, retirement was the most common reason for not working, followed by illness and disability [15]. Well-documented data have identified many individual and macro-level reasons which impact on the decision to retire earlier [8]. Some of the most important factors are the current financial situation and health status. According to Bazzoli's research, the economic condition as well as health can make people decide to retire early [16]. The unemployment and employment rates themselves can also influence people's decision regarding early retirement. Long-term unemployed people prefer to define themselves as retired, rather than being stigmatized by others as unemployed. What is more crucial, people do not necessarily want to work. Research conducted in Poland has shown that some people aged 45-69, who are still occupationally active, declare that they want to retire as soon as possible (> 50\% of respondents) [17]. Another Polish research has identified the most common reasons for early retirement, with the health status being the most frequent reason for premature withdrawal from occupational activity, followed by the uncertainty of employment and chronic work fatigue [18].

In turn, some work characteristics, like physical work, long working hours or low pay, could also encourage people to withdraw from the labor market [8]. According to Karasek's demand-control model [19] and Siegrist's effort-reward imbalance model [20], mental well-being can also affect job satisfaction, though the 2 models mentioned emphasize the negative consequence of job stress. In his study, Siegrist [21] summarized and discussed the current state of empirical evidence linking psychosocial stress at work to the risk of cardiovascular diseases. The relationship between the occupational status and health consequences of employment, and in particular working environment, was confirmed [22]. In turn, Siegrist and Theorell [23] explained how hazardous working conditions could exacerbate the disease burden by contributing to both poor health and the development of social inequalities in health. This tendency could be even more visible in Poland than in other European countries, due to a high percentage of Polish workers who are more likely, compared to workers in most European Union (EU) countries, to report that their health and safety is at risk because of their work [24]. These factors could favor an early retirement decision.

Research has shown that there is a discrepancy between women and men as regards retirement as a reason for not 
being employed. This can result from different reasons for being occupationally inactive. For example, caring for the oldest or the youngest generation is a much more common reason to resign from work for women than for men, whereas performing occupations requiring a greater physical strength, and thus difficult to perform in the middle and older age, is more common for men [13,14].

The early retirement trend seems to be one of the most important challenges for the labor market. If the tendency continues, in the near future there will be only 1 employed person per every retired person in European countries [3], and it is hard to accept the consequences of this trend. From the financial perspective, this situation is no longer feasible [27], especially when the funds spent on retirement pays constitute only a part of the total public spending on older non-workers [28].

Given these trends and the social consequences of early retirement, there is a social and economic need for employees to extend their working years. Thus, it is important to identify the unique risk factors for this decision.

\section{Aim}

This paper identifies individual and institutional causes of withdrawal from the labor market, as well as explores the views of Polish stakeholders on existing strategies for the occupational re-integration of persons with chronic diseases (PwCDs).

The authors put together the results of 2 surveys: one targeted at the inclusion in the labor force and the other focused on the circumstances which appear crucial for staying occupationally active as long as possible.

Therefore, the following hypotheses were formulated:

1. The most significant factor which excludes people from the labor market is age. Until now, the most widely studied individual predictor of early retirement has been age. Several reports have demonstrated the crucial role of age with regard to early retirement. For example, a Danish study showed a significant associa- tion of age with the decision to stop working before attaining the official retirement age, as odds would grow with the increasing age [29]. In Poland, the employment rate has decreased together with the increasing age (LSF 2015).

2. Health as well as socio-demographic and occupational factors constitute barriers for older workers to staying active on the labor market.

Retirement decisions made by people who decide to get their benefits earlier than their normal retirement age are not only health-related but also connected with many factors, such as the financial situation, the level of education, and work characteristics. Epidemiological data are indicative of the number of chronic diseases which decrease the activity rate [30], especially among older workers. There is much evidence that a long-term illness increases the risk of economic deprivation, due to unemployment or economic inactivity [21-23], and impacts on the loss of potentially productive life years of working age persons [34]. Cross-sectional research conducted on the Italian working population approaching the statutory retirement age confirmed that people with poorer health were more likely to retire earlier [35].

Despite the evidence on the significant meaning of health in retirement decisions, it is also necessary to highlight the role of the financial situation. In accordance with the life course approach, a rational worker should compare the expected sum of early retirement pay with income which he/she could get if he/she stayed occupationally active, and then choose the most beneficial option [36]. This theory suggests that household income is a factor determining the early retirement decision: a higher household income decreases the risk of an early retirement decision. The Danish Nurse Cohort Study has shown that earning high income reduces the risk of early retirement [37]. The same findings have been obtained in German and the Dutch studies [36]. It is necessary to stress that people with a university degree have a tendency to shorten their 
working time (bridge employment) rather than leave the labor market. For example, Wang et al. found that retirees who had completed fewer years of education were more likely to engage in full retirement than in bridge employment [38].

The second hypothesis indicates work-related factors as a barrier to staying occupationally active for older workers. Most of the results suggest that work-related variables influence retirement decisions [39]. An analysis based on the SHARE Study (Survey of Health, Ageing and Retirement in Europe Study) has shown that unfavorable work-related factors, such as high physical work demands, time pressure or low rewards in combination with high demands, increase the probability of an early exit [40].

\section{MATERIAL AND METHODS}

The results obtained from "The Collaborative Research on Aging in Europe" (COURAGE in Europe) were complemented by the results of the European research project entitled "PATHWAYS: Participation To Healthy Workplaces And inclusive Strategies in the Work Sector" (the PATHWAYS project). The analysis was performed on cross-sectional data from COURAGE in Europe, which was a 3-year project involving 12 partners from 4 European countries (Italy, Finland, Poland and Spain), and the World Health Organization. The main survey to evaluate the determinants was conducted by the partners in Finland, Poland and Spain, where the survey was administered to a sample of 10800 persons and was completed in March 2012. The survey in Poland covered a total of 4071 respondents. For the purposes of this study, only the results obtained in Poland were taken into account. The participants were interviewed face-to-face in their own homes, with Computer-Assisted Personal Interviewing (CAPI) [53].

The PATHWAYS project was a 3-year EU-funded project that involved 12 partners from 10 European countries, namely Austria, Belgium, Czech Republic, Germany, Greece,
Italy, Norway, Poland, Slovenia and Spain. Within the project, strategies supporting the occupational integration and re-integration of PwCDs were identified and evaluated in terms of their effectiveness. The material and methods from both projects are presented below (Table 1). This analysis gives an opportunity to compare the qualitative and quantitative data. The applied methods made it possible to confront the reasons for withdrawal from the labor force of people who did not attain the retirement age, with the new tendencies aimed at remaining on and/or returning to the labor market by PwCDs. The presentation of these 2 perspectives, from a micro- and macro-level, also gave a full picture of the challenges faced by the modern labor market. Both projects were approved by the Ethical Commission.

\section{RESULTS}

The most important results of the study were compiled and are presented below. At first, the results of COURAGE in Europe were described, and then the results of the PATHWAYS project. This made it possible to develop a multi-level situation analysis, and identify individual, occupational, and institutional factors potentially encouraging people to withdraw from the labor market before attaining the official retirement age. A cross-sectional study of the population provided a framework for evaluating the solutions and recommendations on the macro-level in the area of public health.

The application of multi-level methods allowed the authors to identify the emerging challenges to be faced by the modern labor market.

\section{Results of COURAGE in Europe}

Individual reasons for not working

- Being retired/perceived as "too old" was the most frequent reason for not being employed: more common for men than for women.

- The respondents declared health as a reason for not working. 


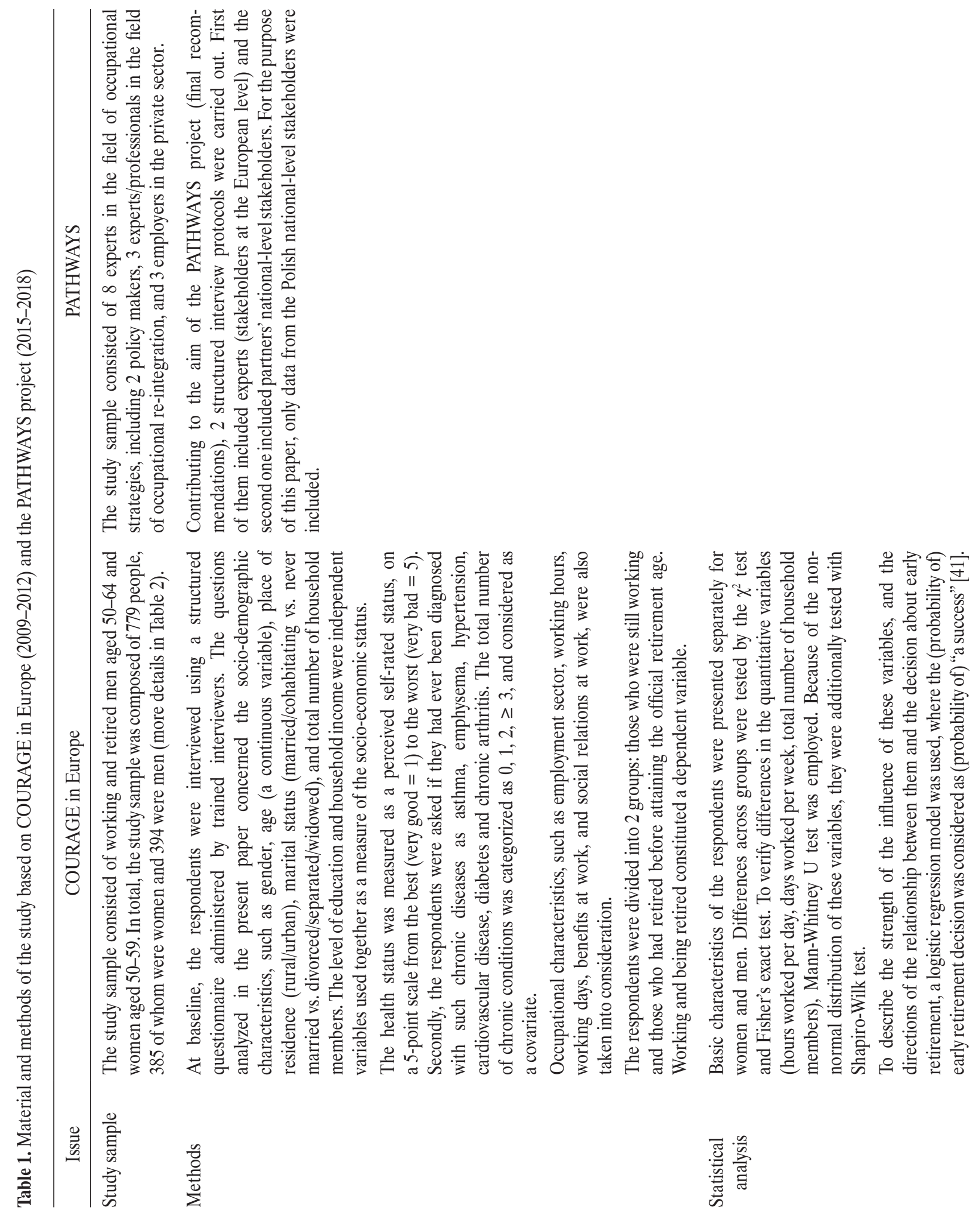



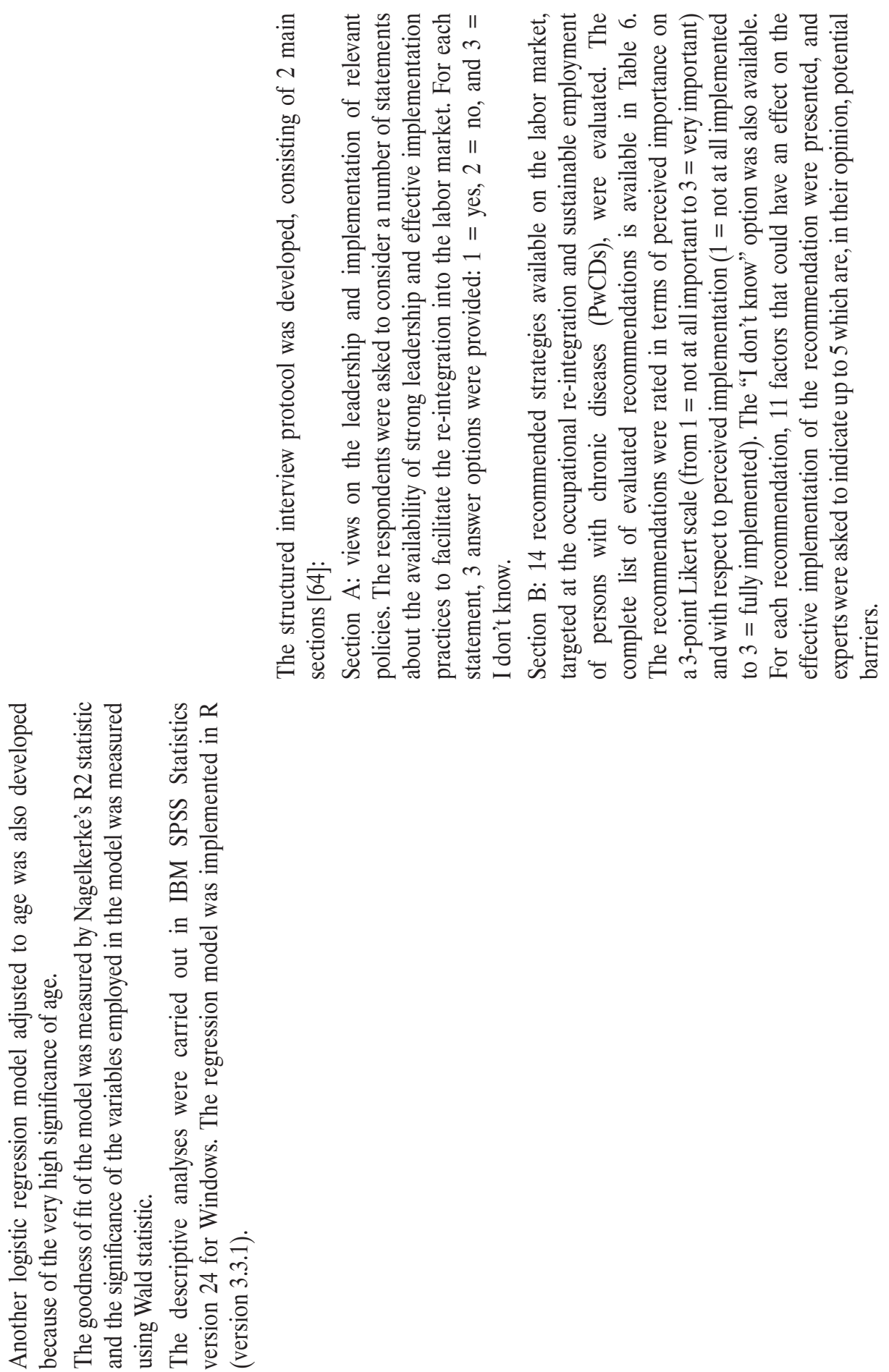

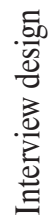


Table 2. Characteristics of the participants, based on COURAGE in Europe (2009-2012)

\begin{tabular}{|c|c|c|c|}
\hline \multirow{2}{*}{ Variable } & \multicolumn{2}{|c|}{$\begin{array}{l}\text { Participants } \\
(\mathrm{N}=779)\end{array}$} & \multirow{2}{*}{$\mathrm{p}$} \\
\hline & $\begin{array}{c}\text { women } \\
(\mathrm{N}=385)\end{array}$ & $\begin{array}{c}\text { men } \\
(\mathrm{N}=394)\end{array}$ & \\
\hline 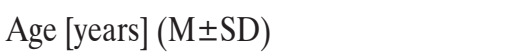 & $54.44 \pm 2.62$ & $57.32 \pm 4.25$ & - \\
\hline Place of living [\%] & & & $0.696^{\mathrm{a}}$ \\
\hline urban & 63.4 & 64.7 & \\
\hline rural & 36.6 & 35.3 & \\
\hline Marital status [\%] & & & $0.002^{\mathrm{a}}$ \\
\hline never married & 15.1 & 9.6 & \\
\hline married/cohabiting & 65.2 & 76.6 & \\
\hline widowed/divorced & 19.7 & 13.7 & \\
\hline Level of education [\%] & & & $<0.001^{\mathrm{a}}$ \\
\hline primary or lower & 8.6 & 8.1 & \\
\hline vocational & 23.6 & 41.6 & \\
\hline high school & 40.8 & 34.5 & \\
\hline university & 27 & 15.7 & \\
\hline Household members (median [Q1-Q3]) & $2(2-3)$ & $2(2-3)$ & $0.068^{c}$ \\
\hline Household income [\%] & & & $0.672^{\mathrm{a}}$ \\
\hline first quintile & 20 & 17.5 & \\
\hline second quintile & 15.1 & 14.5 & \\
\hline third quintile & 16.6 & 14.5 & \\
\hline fourth quintile & 24.4 & 26.6 & \\
\hline fifth quintile & 23.9 & 26.9 & \\
\hline Self-rated health [\%] & & & $0.097^{\mathrm{b}}$ \\
\hline very good & 7.8 & 9.1 & \\
\hline good & 51.4 & 42.1 & \\
\hline moderate & 35.3 & 40.4 & \\
\hline bad & 4.9 & 7.4 & \\
\hline very bad & 0.5 & 1 & \\
\hline Chronic diseases [\%] & & & $0.024 a$ \\
\hline 0 & 52.7 & 43.7 & \\
\hline 1 & 30.9 & 32.5 & \\
\hline 2 & 11.7 & 18.3 & \\
\hline$\geq 3$ & 4.7 & 5.6 & \\
\hline
\end{tabular}


Table 2. Characteristics of the participants, based on COURAGE in Europe (2009-2012) - cont.

\begin{tabular}{|c|c|c|c|}
\hline \multirow{2}{*}{ Variable } & \multicolumn{2}{|c|}{$\begin{array}{l}\text { Participants } \\
(\mathrm{N}=779)\end{array}$} & \multirow{2}{*}{$\mathrm{p}$} \\
\hline & $\begin{array}{c}\text { women } \\
(\mathrm{N}=385)\end{array}$ & $\begin{array}{c}\text { men } \\
(\mathrm{N}=394)\end{array}$ & \\
\hline Currently working [\%] & & & $0.1^{\mathrm{a}}$ \\
\hline yes & 77.9 & 72.8 & \\
\hline no & 22.1 & 27.2 & \\
\hline Work sector [\%] & & & $<0.001^{\mathrm{b}}$ \\
\hline public & 59.5 & 42.9 & \\
\hline private & 31.7 & 43.7 & \\
\hline self-employed & 8.6 & 12.2 & \\
\hline informal employment & 0.3 & 1.3 & \\
\hline Benefits & & & $0.287^{\mathrm{a}}$ \\
\hline no & 40 & 36.3 & \\
\hline yes & 60 & 63.7 & \\
\hline Relations with colleagues [n] & & & $0.863^{\mathrm{a}}$ \\
\hline with no one & 6 & 6.9 & \\
\hline with a few & 67.5 & 66.2 & \\
\hline with everyone & 26.5 & 26.9 & \\
\hline \multicolumn{4}{|l|}{ Work time (Me (Q1-Q3)) } \\
\hline $\mathrm{h} /$ day & $8(8-8)$ & $8(8-9)$ & $<0.001^{\mathrm{c}}$ \\
\hline days/week & $5(5-5)$ & $5(5-6)$ & $<0.001^{\mathrm{c}}$ \\
\hline
\end{tabular}

${ }^{\text {a }}$ Chi ${ }^{2}$ test was used.

${ }^{\mathrm{b}}$ Fisher's exact test was used.

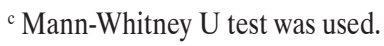

Bold values denote statistical significance at the $p<0.05$ level.

- Women (11.8\%) more often than men $(3.8 \%)$ indicated home duties as a reason for not-working.

A relatively high percentage of women $(6.9 \%)$ and men $(7.9 \%)$ did not work because of difficulties with finding a job. In this group, almost $7 \%$ of women were laid off, i.e., 4 percentage points more than men.

\section{Individual determinants}

The logistic regression analysis which shows a prediction of early retirement was presented in Table 3 for women and in Table 4 for men.
Age is the strongest factor correlating with being or not being retired.

Marital status

- Among married or cohabiting women, the likelihood of early retirement was 6 times higher than among single women.

- Widowed/divorced women were more likely to retire earlier than those who had never been married.

- As regards men, the odds of withdrawal from the labor market before attaining the official retirement age were 


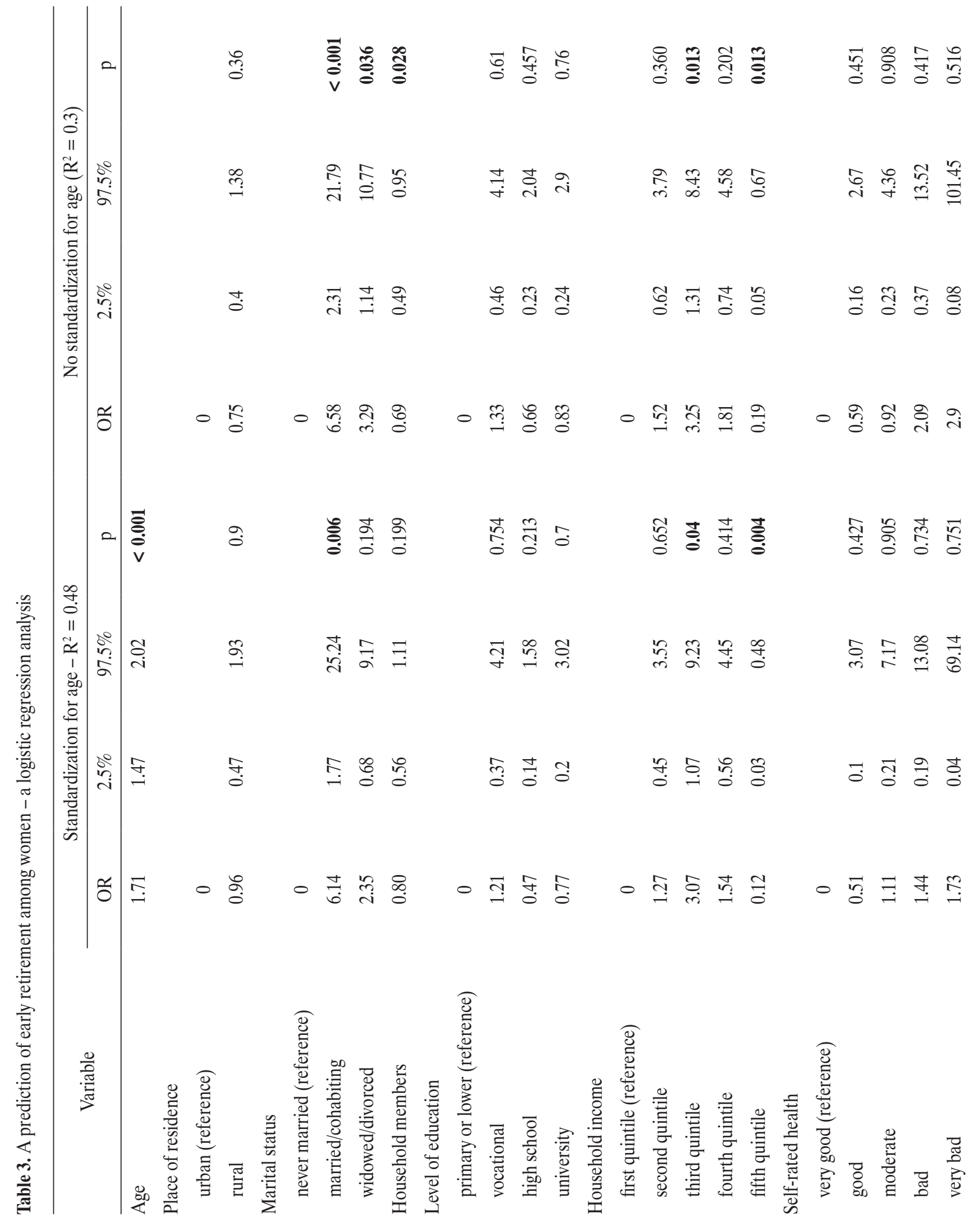




$$
\begin{aligned}
& \text { ڤొ }
\end{aligned}
$$

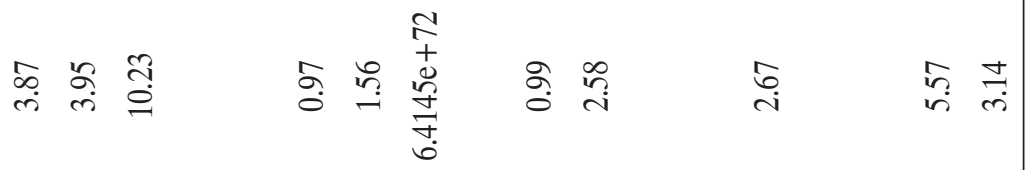

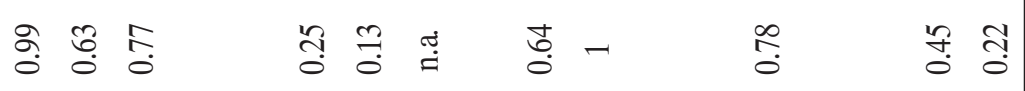

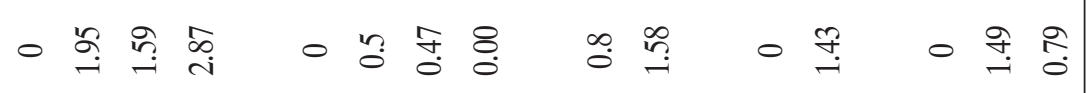

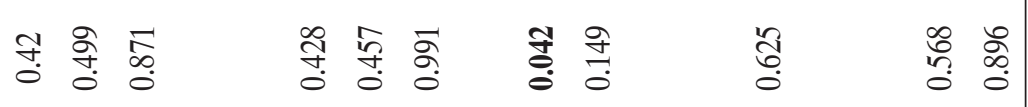

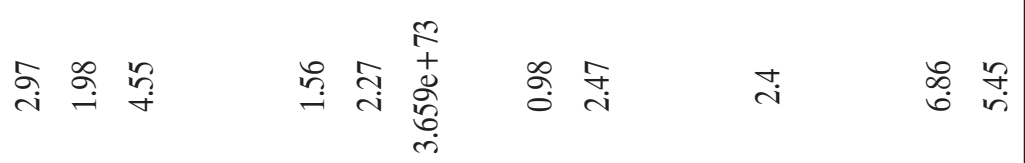

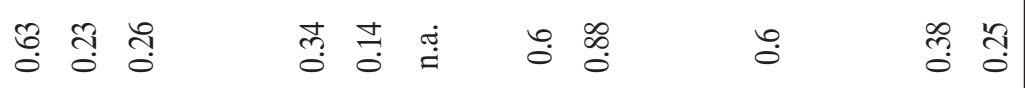

$$
\begin{aligned}
& \text { - ติ }
\end{aligned}
$$

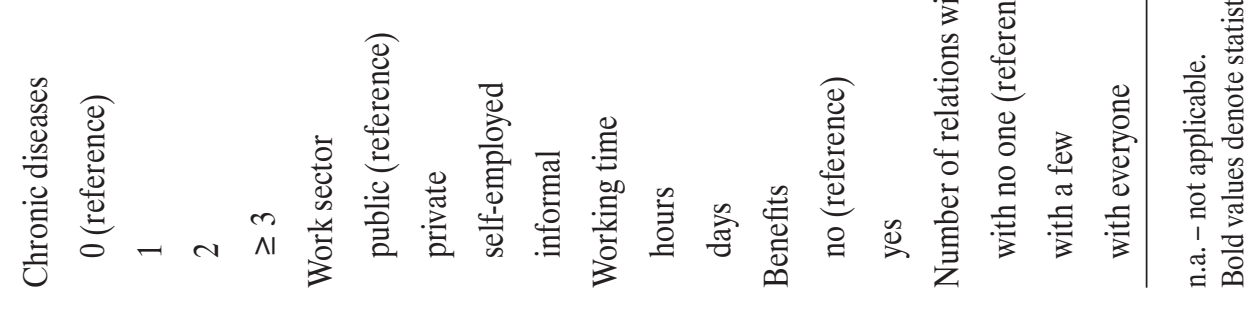




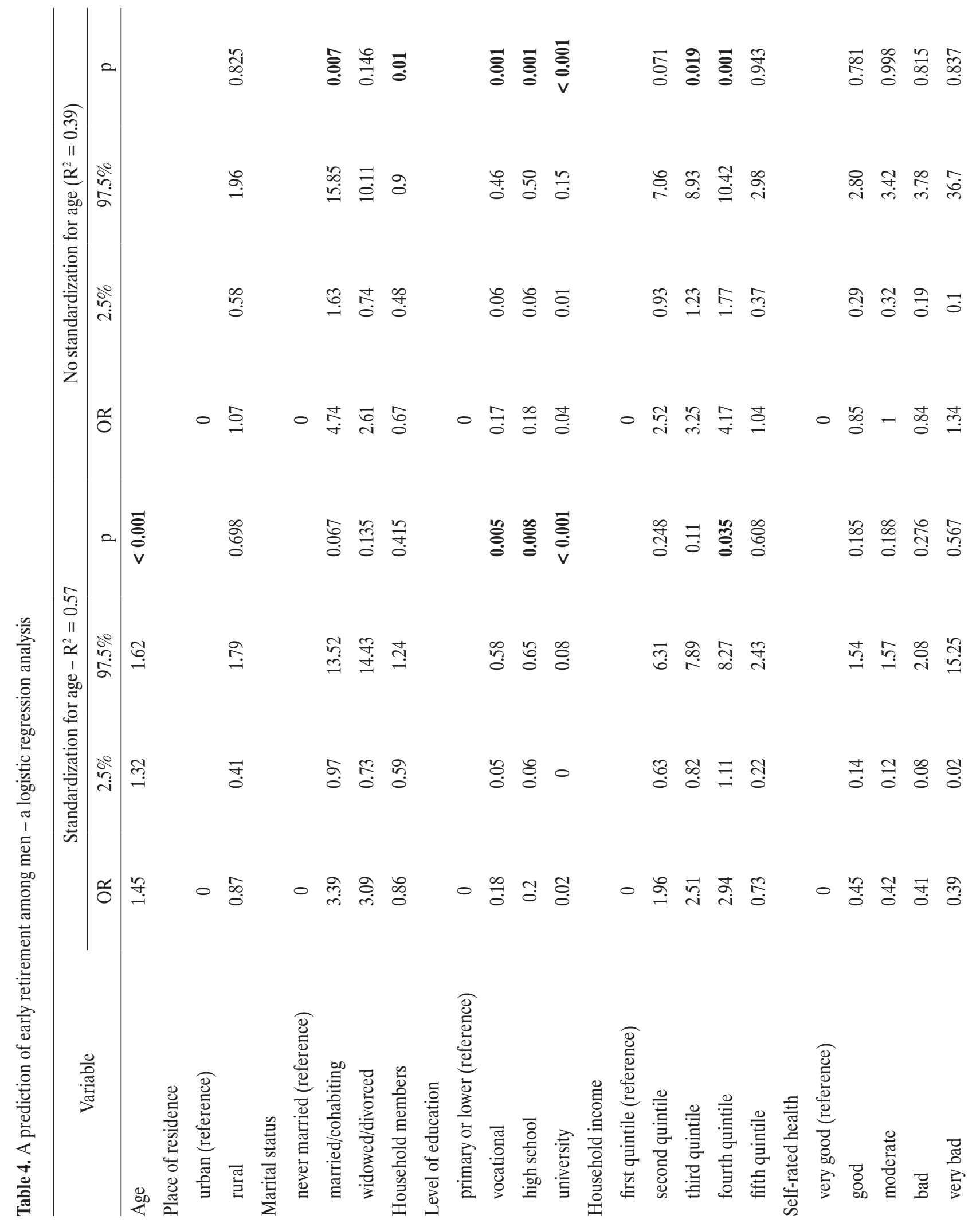




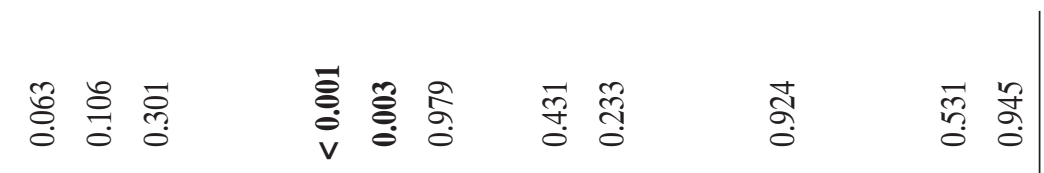

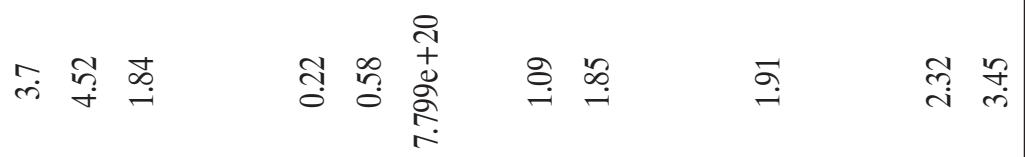

$$
\begin{aligned}
& \text { ఏ. } \\
& \text { ○ }
\end{aligned}
$$

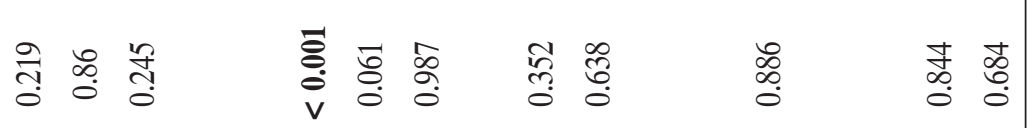

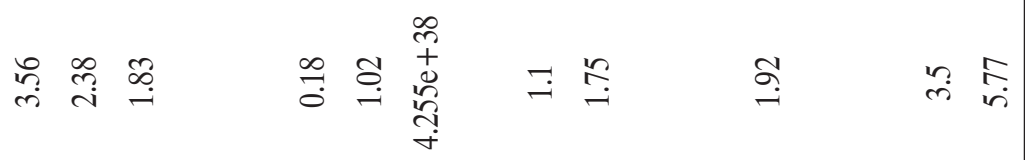

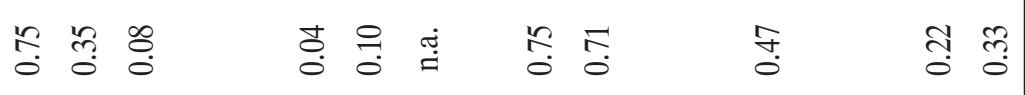

$$
\begin{aligned}
& \text { - }
\end{aligned}
$$

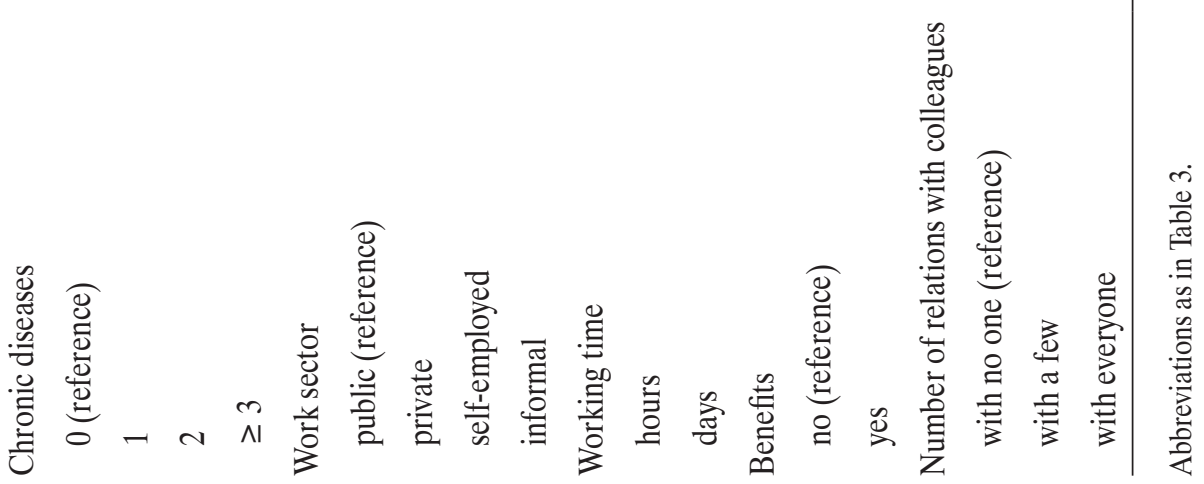


higher among those who were married or cohabiting than among those who had never been married.

\section{Household income}

- Women who declared the highest household income, regardless of age, were less likely to withdraw from the labor market than women who earned the least.

- Women who declared household income in the third quintile were more likely to retire before attaining the official retirement age.

- As regards men, being in the fourth household income quintile was relevant for deciding on early retirement. The greater chances of being retired before attaining the official retirement age were among those who were in the third and fourth household income quintiles, compared to the reference category (the first quintile).

\section{Level of education}

- Among men, the level of education acted in favor of a prolonged career. The odds ratio determined the likelihood of earlier retirement in relation to the reference category (no education/primary education).

- Men with high school education had $80 \%$ lower odds of deciding on early retirement in the first model, and $82 \%$ in the second model, than those with primary education or no education. Higher education also reduced the chance of early withdrawal from the labor market. This correlation was very strong ( $98 \%$ in the first and $96 \%$ in the second model).

- The level of education was not a significant factor in the case of women.

\section{Household members}

- In the second model, increasing the number of family members decreased the odds of early retirement by $31 \%$ for women and by $33 \%$ for men.

\section{Work characteristics}

- Among men who worked in the private sector or were self-employed (in the second model), the odds of withdrawal from the labor market before attaining the official retirement age were lower than among those who were employed in the public sector.

- Among women working in the private sector, the odds of early retirement (in the second model) were 50\% lower than among public sector employees.

- Working hours were a significant factor for women: the more they worked, the less likely they were to retire early.

- Work benefits and good relations with colleagues did not influence the decision to retire early.

Health

- No relationship between self-rated health and early retirement was noted. In addition, the authors did not observe any correlation between the number of chronic diseases and early retirement, either among women or men

\section{Results of the PATHWAYS project}

System availability

- According to stakeholders, most of the occupational reintegration strategies were perceived as not being sufficiently available (Table 5).

- Stakeholders did not refer to the availability of work re-integration strategies aimed at reducing unemployment, adequate legislation conductive to re-integration into the open labor market, or the implementation of re-integration policies.

\section{Policy recommendations}

The PATHWAYS project results proved the importance of all the recommendations (Table 6).

- All the participants agreed that the Recommendations on Access to adequate and customized employ- 
Table 5. Views on the availability of occupational re-integration strategies $(\mathrm{N}=8)$

\begin{tabular}{|c|c|c|}
\hline Statement & Yes & No \\
\hline Unemployment reduction among PwCDs is currently very high on the national agenda. & 1 & 7 \\
\hline $\begin{array}{l}\text { The existing national legislation for reducing unemployment among PwCDs on the open labor } \\
\text { market is adequate. }\end{array}$ & 0 & 7 \\
\hline The existing national legislation for re-integrating PwCDs into the open labor market is adequate. & 0 & 7 \\
\hline $\begin{array}{l}\text { Developing strategies for re-integrating PwCDs into the open labor market is a high priority } \\
\text { on the national agenda. }\end{array}$ & 2 & 6 \\
\hline $\begin{array}{l}\text { The implementation of policies for the occupational re-integration of PwCDs is effectively } \\
\text { coordinated at the national level. }\end{array}$ & 0 & 8 \\
\hline $\begin{array}{l}\text { The implementation of policies for the occupational re-integration of PwCDs is effectively } \\
\text { coordinated at the local level. }\end{array}$ & 1 & 7 \\
\hline $\begin{array}{l}\text { At the national level, specific outcome measures have been set for the evaluation of policies } \\
\text { targeted at the occupational re-integration of PwCDs. }\end{array}$ & 1 & 7 \\
\hline $\begin{array}{l}\text { The implementation of national policies for the occupational re-integration of PwCDs } \\
\text { is supported by specialists in the area of occupational integration. }\end{array}$ & 4 & 2 \\
\hline $\begin{array}{l}\text { Service providers are well informed about the rights of PwCDs concerning } \\
\text { their occupational re-integration. }\end{array}$ & 3 & 3 \\
\hline $\begin{array}{l}\text { Service providers are well informed about the available services supporting the occupational } \\
\text { re-integration of PwCDs. }\end{array}$ & 3 & 3 \\
\hline
\end{tabular}

PwCDs - persons with chronic diseases.

ment services at the local level, and the Availability of workplace adjustments based on individual functioning were very important. The participants claimed that these 2 recommendations were not implemented (at all or implemented only partially).

- Recommendations 5 (Participation in employment activation programs), 6 (Promotion of a person-centered approach), 9 (Development of integrated employment support systems encompassing different sectors) and 14 (Services to employers for managing illness-related long-term absences and return-to-work mechanisms) were considered very important by the vast majority of stakeholders.

- Regarding the level of implementation, according to the majority of stakeholders, all recommendations were not implemented at all, or were implemented only partially. Only 2 recommendations $(6,8)$ were fully implemented according to 2 stakeholders.

\section{Potential barriers that affect the implementation process}

As shown in Table 7, the most frequently reported barriers were:

- inadequate legislation,

- the lack of awareness,

- stigma and discrimination.

- the lack of resources and the lack of expertise were 2 additional barriers indicated by experts.

Based on the data, there are 3 main factors which encourage people to withdraw from the labor market before attaining the official retirement age. Figure 1 presents the multi-level estimates for retirement decisions. The factors that increase the likelihood of going on retirement include age, being in a relationship, a higher level of education in the case of men (and conversely in the case of women), a higher household income and an increasing number of household members. The analysis has revealed that work characteristics constitute a significant push variable for 


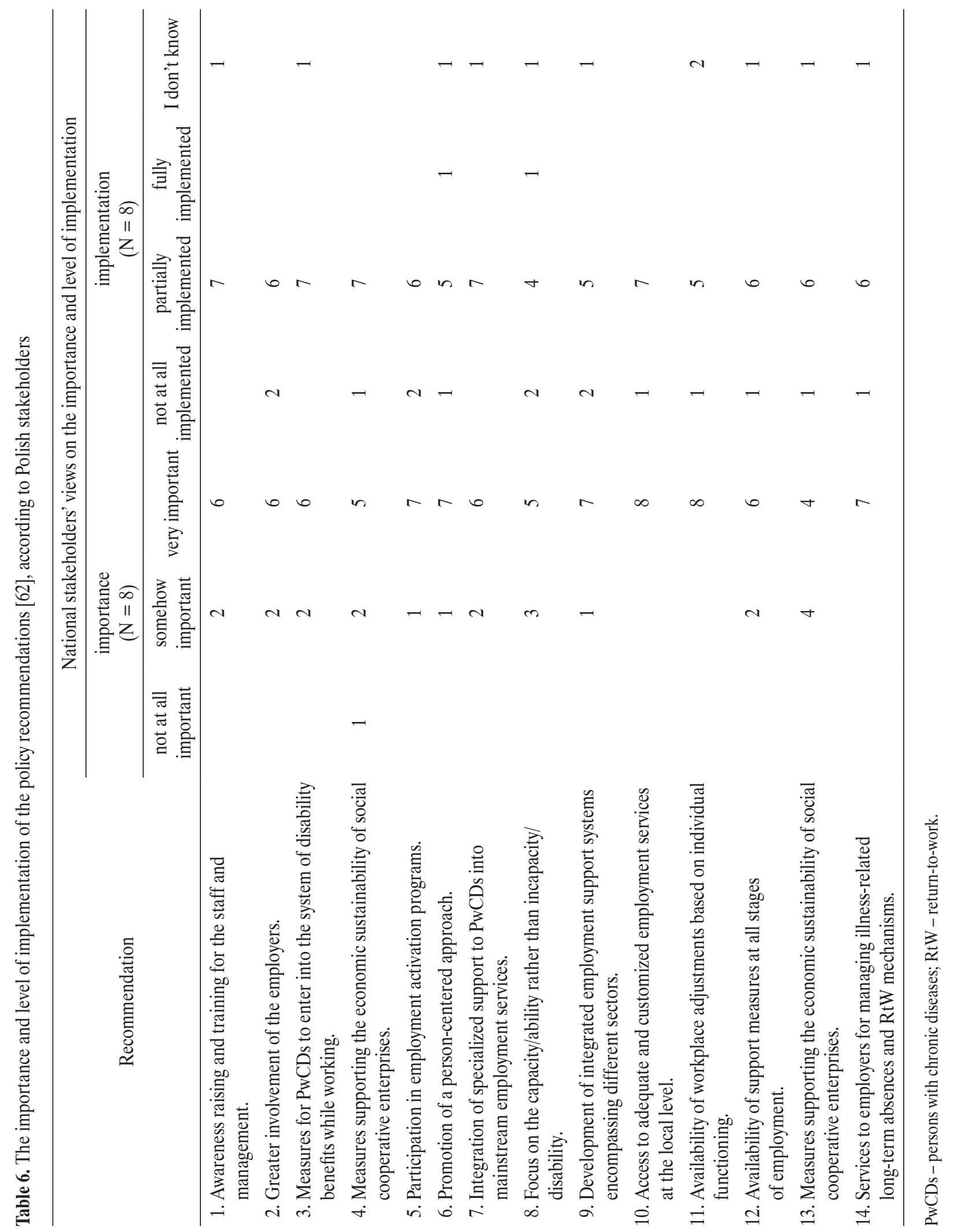




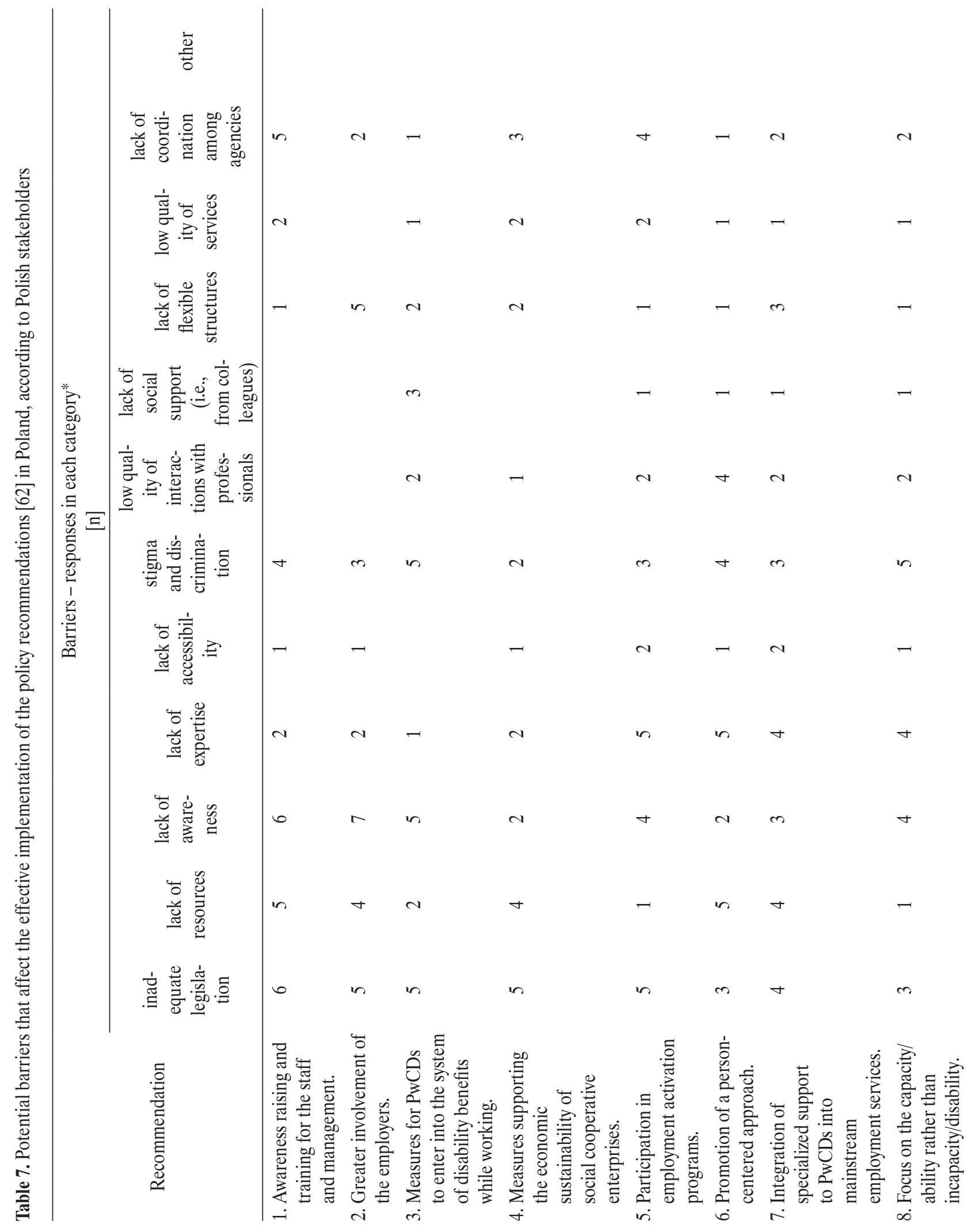




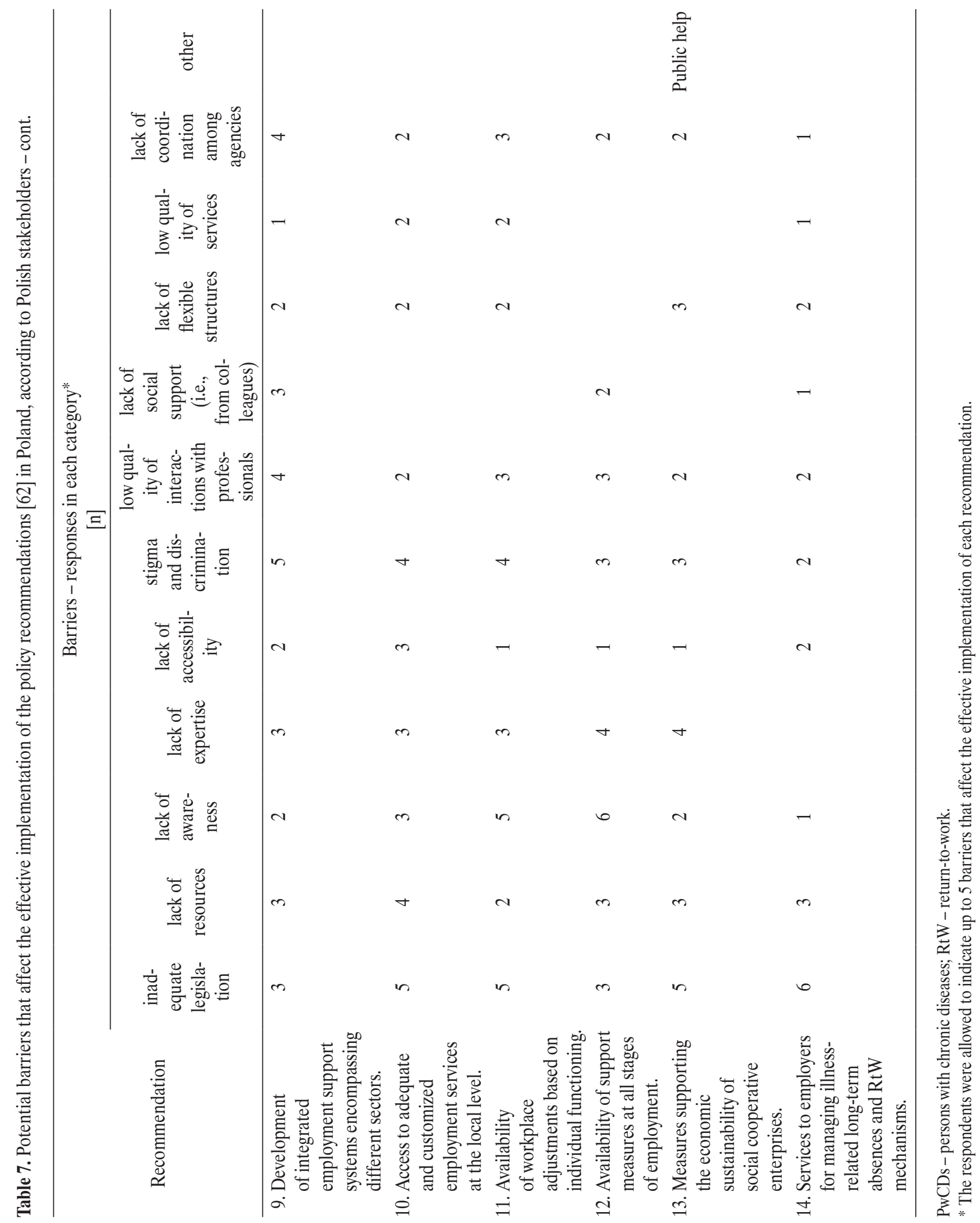




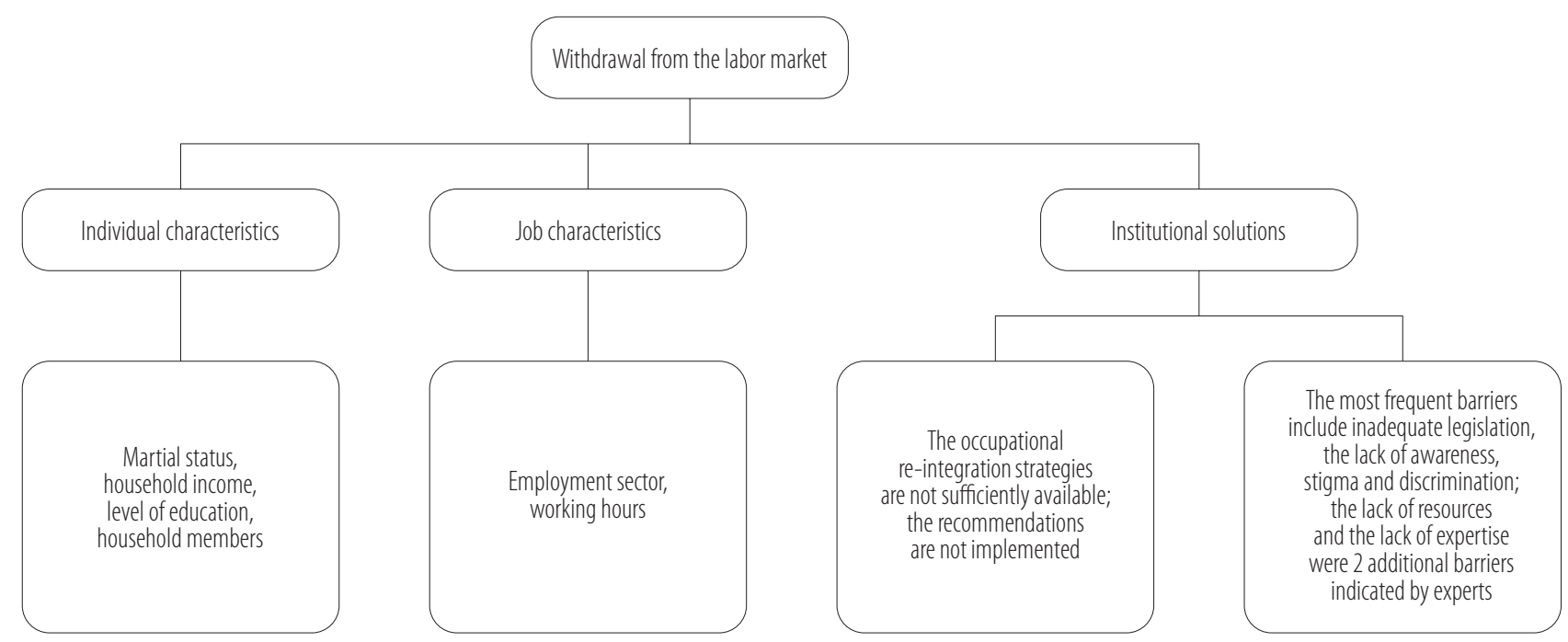

Figure 1. Factors which determine early withdrawal from the labor market

older workers, especially in terms of the employment sector and working hours. For men who worked in the public sector, the odds of ceasing work prematurely were higher than for those who worked in the private sector or were self-employed (in the second model). Taking into account the working hours, the more working hours women had, the lower were the odds of their ceasing work prematurely. Finally, the PATHWAYS project results have indicated that institutional solutions were crucial to staying occupationally active. The respondents stressed that the adequate strategies were unavailable and recommendations were not implemented. Potential barriers that affect the implementation process were also identified.

\section{DISCUSSION}

The aim of the study was to identify individual and institutional causes of withdrawal from the labor market, and to explore the views of Polish stakeholders on existing strategies for the occupationalre-integration of PwCDs. As studies have shown, European countries have to deal with the problems of aging workforce, an increasing number of chronic diseases, and the dwindling resources of labor force. The need to keep people occupationally active seems to be crucial for the European labor market. As stated in the introduction, the decision to cease work prematurely reflects a combination of many different factors, such as individual determinates, work characteristics, personal convictions, and systemic solutions. In terms of identifying the early retirement trend, it is important to determine the impact of institutional mechanisms on individual outcomes. Research has shown that the macro-level situation is crucial to ceasing work prematurely. For example, the growing unemployment rate in the country leads to a higher propensity of early retirees [42]. Nevertheless, in Poland stakeholders reported the lack of effective coordination in the implementation of policies for the occupational reintegration of PwCDs. The vast majority considered the existing national legislation as being inadequate when it comes to reducing unemployment and promoting the occupational re-integration process. They also identified a lot of barriers for the labor force.

The findings of the study on the socio-demographic characteristics and occupational determinants of transition from employment to early retirement are consistent with similar research conducted in Europe, including Poland. Generally, people who are older are more likely to opt 
for complete withdrawal from the labor market before attaining the official retirement age [43]. This hypothesis has been confirmed in the research. Rationally, one of the most crucial factors of retirement is age, as the older the people get, the more likely they are to retire [44]. In this study, in order to exclude the impact of age on the results, this factor was considered only in the first model. This was the main reason for using 2 models in the research: one including age and the other without this variable.

Based on the data obtained from COURAGE in Europe, the most common reason for not working in a group of people on early retirement is age. The PATHWAYS data presented the extent to which the corresponding solutions were implemented, as well as made it possible to identify barriers for the labor force. The results confirmed the validity of this study; people who were close to the retirement age declared retirement as the main reason for not working. Health was also a frequent cause of being unemployed, but it was not a significant issue in the established models, especially at the level of individual responses indicating health as an explanation for being out of the labor market. However, various studies have reported a strong correlation between individual health and the experience of unemployment [45]. According to the "justification hypothesis," the lack of relationship in this analysis could result from the fact that the respondents, while opting for early retirement, might justify their decisions by declaring poor health, but analyzing health together with other variables revealed that health, as a separate variable, was not significant.

Research has shown that the decision to retire early is affected by many factors simultaneously. This confirms the second hypothesis formulated in this article, regarding the numerous barriers to remaining occupationally active. A multitude of barriers to extending working life, as well as their multi-dimensional character (from individual to systemic), were shown in another study, also conducted in Poland [17]. This study has proven that, in most cases, fam- ily could play an important role. Being a homemaker influences people's (especially women's) decision not to stay occupationally active. What is more, these findings show that people who are married or cohabiting have higher odds of premature withdrawal from workforce than those who are single. These findings are in line with several studies confirming that having a partner leads to earlier retirement $[35,36]$. According to Belgian research on teachers, the tendency to resign from work is even higher among those people whose partner is still working [43]. It could result from a better and more settled financial situation, with 1 partner still working. The above pattern could suggest that withdrawal from workforce is not only an individual decision, but it also depends on the family context. Several reports have demonstrated that the economic status is a predictor of retirement decisions, but the influence of income on earlier withdrawal from the labor market tends to be ambiguous. Researchers explain it in 2 ways: on the one hand, poverty can be a cause of early retirement because it causes poor health, which makes people incapable of work. On the other hand, poverty can also force people to seek employment and postpone their retirement [48].

In the present study, the authors noted that household income constituted a great predictor of an early retirement decision: a higher household income decreased the risk of an early retirement decision. The lack of interest in early retirement among those who earn the highest income can be explained by the fact that in this group retirement would significantly reduce the standard of living to which they are accustomed. This tendency is clearly visible for women regardless of age, and for men, but only after eliminating the age variable from the model. In another Polish study conducted on blue-collar workers, a poor economic condition of the household was found to constitute a significant factor in early retirement decisions [49]. It means that employees assessing their material situation as good prefer to work longer than those who are in a worse 
financial situation. Rationally, it can be explained by the fact that workers will retire only if they feel that the future economic conditions would allow them to support their consumption needs during retirement.

In turn, the consumption needs are related to the previous financial situation and may reflect different levels of people's needs: retirement will change the standard of living especially among those whose income was high. People whose earnings oscillated around the third quintile were more likely to retire early - probably because their standard of living would not change dramatically. The Polish results could also be explained by the functioning of the retirement system, with the retirement pay increasing with the number of working years.

The authors found that higher education decreased the probability of early retirement, but only among men. These findings are in accordance with a Norwegian study which showed that a lower level of education was positively associated with early retirement [25]. Nevertheless, an Italian study showed an opposite correlation [50], similar to the research conducted in the United Kingdom, where higher education increased the probability of a transition into early retirement [36]. In Poland, it could be explained by the fact that people with higher education usually do not have to do blue-collar jobs, in which high physical strength is obligatory. The other explanation assumes that, together with a low educational level and old age, problems related to using new technologies occur more often than among people with higher education. The conclusion that the lower the educational level, the higher the probability of retiring was drawn in the studies making reference to the analysis carried out in the projects entitled "Equal opportunities in the labor market for people aged 50+" [17], and "Retirement behaviour in Poland and the potential impact of pension system changes" [51]. In this study, the authors noted that early retirement was not associated with self-rated health. They did not find any relationship between work and feeling healthy or unhealthy, either for women or men. This result did not change after eliminating the age variable from the model. To be more precise, the authors also included chronic conditions to check if having a long-term disease influenced somebody's decision to retire early. According to the research, having 1, 2, and $\geq 3$ long-term diseases did not change the decision to retire. These results are in opposition to several other studies which have shown that self-rated health influences the probability of withdrawal from the labor market and also predicts the risk of early retirement $[40,41]$.

The importance of self-rated health on early retirement decisions was revealed by longitudinal studies, a literature review and a focus group conducted by van den Berg, Elders, and Burdorf. Their results additionally highlighted the role of workload with regard to remaining occupationally active [54]. Research based on the European Household Panel Survey has shown a higher chance of retiring the following year among people aged $>55$ with poor health than among those with good health. In the same study, poor health was also a greater risk factor for remaining unemployed among men than among women [32]. Finnish studies have shown that poor self-rated health is a very strong predictor of premature retirement, especially among men aged 42-60 [55].

Some studies of early retirement decisions have analyzed the relationship between occupation variables, work environment and withdrawal from the labor market $[4,36,44,45]$. This relationship is best exemplified in the work sector. In the present study, the odds of early retirement decreased among men who were working in the private sector, as well as among those who were selfemployed. This relationship was also observed among women, but only after eliminating the age variable from the model. These findings are in line with the results obtained for Germany and the United Kingdom, in which those who were employed in the public sector had higher odds of early retirement. The relationship in question was 
contrary to the findings regarding the Netherlands, where early retirement decisions were more common for people working in the public sector [36].

The present study has verified the influence of work environment on the decision to withdraw from the labor market. Nevertheless, there was no relationship between work benefits and the decision to retire. The authors also did not notice any impact of close relations with colleagues on the withdrawal from labor market before attaining the official retirement age. This result is in opposition to the findings by van den Berg, Elders and Burdorf who highlighted the impact of social support from colleagues on staying occupationally active [54]. Work environment constitutes a crucial factors; however, according to the respondents, there is no adequately implemented solution which could lead to increasing the number of people on the labor market. It is of utmost importance to implement strategies which encourage people to enter or return to labor force, such as workplace adaptation to individual needs, and/or customized employment services at the local level. Other research has proven that employment strategies comprising various types of support result in a growing number of workers with chronic diseases [58,59], and of older age [60].

The necessity of adapting the workplaces to the aging workforce's needs has been identified in "Solidarity of Generations," a Polish governmental program which encompasses such topics as supporting long-term age management, improving working conditions, retaining employment, and counteracting discrimination [61]. Although the Polish society is one of the fastest aging societies in the European Union, there are no solutions or direct legal instruments that would be focused on the workplace adaptation to the needs emerging on the labor market [61]. As part of the PATHWAYS project, a set of policy recommendations [62] for an inclusive labor market in Europe have been developed. This document constitutes the final product of the PATHWAYS project. While all of the rec- ommendations are focused on the needs of people with chronic diseases, most of them could be adapted to improve the situation of people aged $>50$ on the Polish labor market, and to prolong their career.

The real challenge for an aging population is to ensure that the employment sector is capable of adapting to individual people's needs, i.e., to the needs of people witch chronic diseases, people with disabilities, and people of older age. It is essential to encourage people to stay occupationally active by removing the barriers which prevent them from deriving full benefits from being employed, given especially that, as research has proven, an inclusive labor market for all will greatly support health for all [63].

\section{Limitations of the study}

Some limitations must be taken into account in this study. First, a cross-sectional analysis and self-reported data make it impossible to formulate a general statement about causal relationship. The presented data were collected from the current and retrospective point of view, which could lead to overestimation or underestimation of certain events, or even to not remembering certain facts. However, most studies concerning retirement are based on the respondents' retrospective statements, and their findings show that they are trustworthy. The second limitation of this study consists in not encompassing all the possible determinants relevant to the retirement decision and, consequently, it was impossible to reconstruct the whole work history or the quality of marriage/cohabiting. In addition, the authors did not gather any data related to early retirement due to restructuring or winding-up the companies. The authors of this paper were able to consider a number of socio-demographic characteristics and occupational determinants, such as self-rated health, number of chronic diseases, gender, age, place of residence, total number of household members, marital status, level of education, household income, as well as working sector, working hours and days, work benefits, and close relations with col- 
leagues. However, this study did not consider the effects of stress, job satisfaction or working conditions. The authors were also unable to include job seniority due to the lack of data; only a small percentage of respondents answered the questions regarding the time when they started and finished their career. The lack of data may result from the fact that the question concerns a long period of time, and respondents could not remember the year of commencement of their work [43].

Admittedly, the project focused on a group of people with chronic diseases and mental disorders, but as regards the concept of early retirement, this paper took into account a number of factors which encourage people to retire early or which keep them active on the labor market. The final PATHWAYS project results made it possible to develop recommendations of strategies which might help keep people active. European recommendations, as well as the more favorable policies, services and measures can facilitate occupational re-integration and present the possible ways to overcome potential barriers.

\section{CONCLUSIONS}

Given the increased number of people deciding to retire early, it is becoming imperative to identify the factors that may influence such decisions and those which determine them. Thus, policy makers need to understand not only the role of individual-level factors or work characteristics in the process of making early retirement decisions, but also the importance of institutional and macro-level determinants. Such knowledge can help both government bodies as well as human resources departments or company management bodies to develop adequate solutions to make people stay longer on the labor market on the micro- and macro-level.

Nevertheless, this study has demonstrated that, despite the growing awareness of the dwindling resources of labor force, the employment-related challenges faced by PwCDs [64] as well as people who are close to attaining the retirement age remain unaddressed. People decide to retire as soon as their situation allows that. According to experts, there is no legislation to keep them active, and the implementation of re-integration strategies has been assessed as in effective.

People have to know that they are still useful as employees, and it is easier when they are educated and with a good financial condition. However, these are material resources that play a crucial role in staying occupationally active. People withdraw from the labor market only if it is profitable for them: they have enough money, their partner is still working, so they have a double income in their household (a retirement pay and a salary), and provided that this decision does not change significantly their standard of living. Policy makers should make early retirement less attractive and adjust workplaces to the needs of people close to their retirement age. In the PATHWAYS project, certain recommendations for policy makers have been developed. Now, knowing the individual factors encouraging people to cease work prematurely, there is a chance to implement strategies and recommendations, which would prompt people to stay occupationally active as long as possible. This is a crucial challenge to be faced by the modern labor market.

\section{REFERENCES}

1. Harper S. Ageing Societies: Myths, Challenges and Opportunities. New York: Routledge; 2013, https://doi.org/10.4324/97 80203783696

2. Loichinger E, Weber D. Trends in Working Life Expectancy in Europe. J Aging Health. 2016;28(7):1194-213, https://doi. org/10.1177/0898264316656509.

3. OECD. Private Pensions: OECD Classification and Glossary [Internet]. Paris: OECD; 2005 [cited 2018 Mar 6]. Avaliable from: www.oecd.org/daf/fin/private-pensions/privatepensionsoecdclassificationandglossary.html.

4. Cumming E, Henry W. Growing old, the process of disengagement, New York: Basic Books; 1961. 
5. Havighurst RJ. Successful Aging. Gerontologist. 1961;1:813, https://doi.org/10.1093/geront/1.1.8.

6. Atchley RC. A Continuity Theory of Normal Aging. Gerontologist. 1989;29(2):183-90, https://doi.org/10.1093/geront/ 29.2.183.

7. Principi A, Santini S, Socci M, Smeaton D, Cahill KE, Vegeri S, et al. Retirement plans and active ageing: perspectives in three countries. Ageing Society. 2017;38(1):56-82, https://doi.org/10.1017/S0144686X16000866.

8. Lamprianou I. Determinants of Early Retirement in the European Union. J Transnatl Manag. 2012;17(2):137-54, https://doi.org/10.1080/15475778.2012.676966.

9. Settersten RA, Hagestad GO. Cultural Age Deadlines for Educational and Work Transitions. Gerontologist. 1996;36(5):602-13, https://doi.org/10.1093/geront/36.5.602.

10. Settersten RA, Hagestad GO. What's the Latest? Cultural Age Deadlines for Family Transitions. Gerontologist. 1996;36(2):178-88, https://doi.org/10.1093/geront/36.2.178.

11. Szukalski P. Uwarunkowania przemian aktywności zawodowej osób starszych w krajach wysoko rozwiniętych. Studia Demogr. 1998;2(132):53-67.

12. Szukalski P. Searching for Intellectual Roots of Active Ageing. Acta Univ Lodz Folia Oeconomica. 2015;315(4):159-71, https://doi.org/10.18778/0208-6018.315.11.

13. Conde-Ruiz JI, Galasso V. The Macroeconomics of Early Retirement. J Public Econ. 2004;88(9-10):1849-69, https:// doi.org/10.1016/j.jpubeco.2003.12.005.

14. Central Statistical Office [Internet]. Warsaw: The Office; 2016 [cited 2019 Mar 23]. [Labour force survey in Poland]. Avaliable from: https://stat.gov.pl/en/topics/labour-market/.

15. Central Statistical Office [Internet]. Warsaw: The Office; 2018 [cited 2019 Mar 23]. [Labour force survey in Poland in I quarter 2018]. Avaliable from: https://stat.gov.pl/download/ gfx/portalinformacyjny/en/defaultaktualnosci/3293/2/29/1/ labour_force_survey_in_poland_1q_2018.pdf.

16. Bazzoli GJ. The Early Retirement Decision: New Empirical Evidence on the Influence of Health. J Hum Resour. 1985;20(2):214, https://doi.org/10.2307/146009.
17. Wiktorowicz J. Extending working life or retiring? A microeconomic study. Studia Demogr. 2014;2(166):7-37.

18. Szukalski P. To idzie starość. Postawy osób w wieku przedemerytalnym. Warszawa: Instytut Spraw Publicznych; 2008.

19. Karasek R. Job Demands, Job Decision Latitude, and Mental Strain: Implications for Job Redesign. Adm Sci Q. 1979;24(2):285-308, https://doi.org/10.2307/2392498.

20. Siegrist J. Adverse Health Effects of High-Effort/LowReward Conditions. J Occup Heal Psychol House Karasek Theorell La Ferla Levi. 1996;1(1):27-41, https://doi.org/ 10.1037/1076-8998.1.1.27.

21. Siegrist J. Effort-reward imbalance at work and cardiovascular diseases. Int J Occup Med Environ Heal. 2010;2323(33): 279279-85, https://doi.org/10.2478/v10001-010-0013-8.

22. Tobiasz-Adamczyk B, Bartoszewska E, Brzyski P, Kopacz M. Long-term consequences of education, working conditions, and health-related behaviors on mortality patterns in older age. A 17-year observational study in Kraków, Poland. Int J Occup Med Environ Health. 2007;20(3):247-56.

23. Siegrist J, Theorell T. Socio-economic position and health: the role of work and employment. In: Siegrist J, Marmot M, editors. Social Inequalities in Health: New Evidence and Policy Implications. Oxford: Oxford University Press; 2006. p. 73-100.

24. Parent-Thirion A, Vermeylen G, van Houten G, Lyly-Yrjänäinen M, Biletta I, Cabrita J. Fifth European Working Conditions Survey [Internet]. Luxemburg: Publications Office of the European Union; 2012 [cited 2018 May 5]. Avaliable from: https://www.eurofound.europa.eu/pl/publications/report/2012/working-conditions/fifth-european-working-conditions-survey-overview-report.

25. Blekesaune M, Solem PE. Working Conditions and Early Retirement: A Prospective Study of Retirement Behavior. Res Aging. 2005;27(1):3-30, https://doi. org $/ 10.1177 / 0164027504271438$.

26. Raymo JM, Warren JR, Sweeney MM, Hauser RM, Ho J-H. Precarious employment, bad jobs, labor unions, and early retirement. J Gerontol B Psychol Sci Soc Sci. 2011;66(2):24959, https://doi.org/10.1093/geronb/gbq106. 
27. Van Dam K, Van Der Vorst JDM, Van Der Heijden BIJM. Employees' Intentions to Retire Early A Case of Planned Behavior and Anticipated Work Conditions. J Career Dev. 2009;35(3):265-89, https://doi.org/10.1177/0894845308327274.

28. Blundell R, Meghir C, Smith S. Pension incentives and the pattern of early retirement. Econ J. 2002;112(478):C153-70, https://doi.org/10.1111/1468-0297.00031.

29. Lundin A, Lundberg I, Hallsten L, Ottosson J, Hemmingsson T. Unemployment and mortality - a longitudinal prospective study on selection and causation in 49321 Swedish middle-aged men. J Epidemiol Community Health. 2010;64(1):22-8, https://doi.org/10.1136/jech.2008.079269.

30. Magnavita N, Sakowski P, Capitanelli I, La Milia DI, Moscato U, Poscia A, et al. Health promotion for the aging workforce in Poland. Int J Occup Med Environ Health. 2018;31(6):753-61, https://doi.org/10.13075/ijomeh. 1896.01207.

31. Corral A, Durán J, Isusi I. Employment Opportunities for People with Chronic Diseases [Internet]. Brussels: IKEI Research and Consulting; 2014 [cited: 2018 May 5]. Avaliable from: https://www.eurofound.europa.eu/publications/re port/2014/employment-opportunities-for-people-with-chro nic-diseases.

32. Schuring M, Burdorf L, Kunst A, Mackenbach J. The effects of ill health on entering and maintaining paid employment: evidence in European countries. J Epidemiol Community Heal. 2007;61(7):597-604, https://doi.org/10.1136/ jech.2006.047456.

33. Virtanen P, Janlert U, Hammarström A. Health status and health behaviour as predictors of the occurrence of unemployment and prolonged unemployment. Public Health. 2013;127(1):46-52, https://doi.org/10.1016/j.puhe. 2012.10.016.

34. Grammenos S. European comparative data on Europe 2020 \& People with Disabilities [Internet]. Brussels: Academic Network of European Disability experts (ANED); 2013 [cited 2018 Jun 15]. Avaliable from: https://www.disabilityeurope.net/theme/statistical-indicators.
35. Li Ranzi T, d'Errico A, Costa G. Association between chronic morbidity and early retirement in Italy. Int Arch Occup Environ Health. 2013;86(3):295-303, https://doi.org/10.1007/ s00420-012-0765-5.

36. Schils T. Early Retirement in Germany, the Netherlands, and the United Kingdom: A Longitudinal Analysis of Individual Factors and Institutional Regimes. Eur Sociol Rev. 2008;24(3):315-29, https://doi.org/10.1093/esr/jcn009.

37. Friis K, Ekholm O, Hundrup YA, Obel EB, Grønbaek M. Influence of health, lifestyle, working conditions, and sociodemography on early retirement among nurses: The Danish Nurse Cohort Study. Scand J Public Health. 2007;35:25-30, https://doi.org/10.1080/14034940600777278.

38. Wang M, Zhan Y, Liu S, Shultz KS. Antecedents of bridge employment: A longitudinal investigation. J Appl Psychol. 2008;93(4):818-30, https://doi.org/10.1037/0021-9010.93.4.818.

39. Adams GA. Career-Related Variables and Planned Retirement Age: An Extension of Beehr's Model. J Vocat Behav. 1999;55:221-35, https://doi.org/10.1006/jvbe.1998.1679.

40. Kouwenhoven-Pasmooij TA, Burdorf A, Roos-Hesselink JW, Hunink MGM, Robroek SJW. Cardiovascular disease, diabetes and early exit from paid employment in Europe; the impact of work-related factors. Int J Cardiol. 2016;215:332-7, https://doi.org/10.1016/j.ijcard.2016.04.090.

41. McCullagh P, Nelder JA. Generalized Linear Models. London: Chapman and Hall, 1989, https://doi.org/10.1007/9781-4899-3242-6.

42. Fischer JAV, Sousa-Poza A. The Institutional Determinants of Early Retirement in Europe. Gallen: Department of Economics University of St. Gallen; 2006, https://doi. org/10.2139/ssrn.895081.

43. Droogenbroeck F Van, Spruyt B. To Stop or Not to Stop: An Empirical Assessment of the Determinants of Early Retirement Among Active and Retired Senior Teachers. Res Aging. 2014;36(6):753-77, https://doi.org/10.1177/0164 027513519449 .

44. Wang M, Shultz KS, Youssim I. Employee Retirement: A Review and Recommendations for Future Investigation. 
J Manage. 2010;36(1):172-206, https://doi.org/10.1177/0149 206309347957.

45. Schmitz H. Why are the unemployed in worse health? The causal effect of unemployment on health. Labour Econ. 2011;18(1):71-8, https://doi.org/10.1016/j.labeco.2010. 08.005 .

46. Szinovacz ME, Deviney S. Marital Characteristics and Retirement Decisions. Res Aging. 2000;22(5):470-98, https:// doi.org/10.1177/0164027500225002.

47. Lund T, Iversen L, Poulsen KB. Work environment factors, health, lifestyle and marital status as predictors of job change and early retirement in physically heavy occupations. Am J Ind Med. 2001;40(2):161-9, https://doi.org/10.1002/ ajim.1084.

48. Cattell V. Poor people, poor places, and poor health: the mediating role of social networks and social capital. Soc Sci Med. 2001;52(10):1501-16, https://doi.org/10.1016/S0277-95 36(00)00259-8.

49. Szubert Z, Sobala W. Current determinants of early retirement among blue collar workers in Poland. Int J Occup Med Environ Health. 2005;18(2):177-84.

50. Cardano M, Costa G, Demaria M. Social mobility and health in the Turin longitudinal study. Soc Sci Med. 2004;58(8): 1563-74, https://doi.org/10.1016/S0277-9536(03)00354-X.

51. Chlon-Dominczak A. Retirement Behaviour in Poland and the Potential Impact of Pension System Changes. 2009, ENEPRI Research Report No. 63, https://doi.org/10.2139/ssrn.2033650.

52. Alavinia SM, Burdorf A. Unemployment and retirement and ill-health: a cross-sectional analysis across European countries. Int Arch Occup Environ Health. 2008;82(1):3945, https://doi.org/10.1007/s00420-008-0304-6.

53. Elovainio M, Kivimäki M, Vahtera J, Ojanlatva A, Korkeila K, Suominen S, et al. Social support, early retirement, and a retirement preference: a study of 10,489 Finnish adults. J Occup Environ Med. 2003;45(4):433-9, https://doi. org/10.1097/01.jom.0000058334.05741.7a.

54. Van den Berg TIJ, Elders LAM, Burdorf A. Influence of Health and Work on Early Retirement. J Occup
Environ Med. 2010;52(6):576-83, https://doi.org/10.1097/ JOM.0b013e3181de8133.

55. Karpansalo M, Manninen P, Kauhanen J, Lakka TA, Salonen JT. Perceived health as a predictor of early retirement. Scand J Work Environ Health. 2004;30(4):287-92, https:// doi.org/10.5271/sjweh.796.

56. Kubicek B, Korunka C, Hoonakker P, Raymo JM. Work and Family Characteristics as Predictors of Early Retirement in Married Men and Women. Res Aging. 2010;32(4):467-98, https://doi.org/10.1177/0164027510364120.

57. Siegrist J, Wahrendorf M, Von Dem Knesebeck O, Jürges H, Börsch-Supan A. Quality of work, well-being, and intended early retirement of older employees-baseline results from the SHARE Study. Eur J Public Health. 2006;17(1):62-8, https://doi.org/10.1093/eurpub/ckl084.

58. Van Veggel R, Waghorn G, Dias S. Implementing evidencebased supported employment in Sussex for people with severe mental illness. Br J Occup Ther. 2015;78(5):286-94, https://doi.org/10.1177/0308022614567667.

59. Hoffmann H, Jäckel D, Glauser S, Mueser KT, Kupper Z. Long-Term Effectiveness of Supported Employment: 5-Year Follow-Up of a Randomized Controlled Trial. Am J Psychiatry. 2014;171(11):1183-90, https://doi.org/10.1176/appi. ajp.2014.13070857.

60. Barros C, Carnide F, Cunha L, Santos M, Silva C. Will I be able to do my work at 60 ? An analysis of working conditions that hinder active ageing. Work. 2015;51(3):579-90, https:// doi.org/10.3233/WOR-152011.

61. Czarzasty J, Koziarek M, Owczarek D. Work place adaptation to older and disabled workers in Poland [Internet]. Warszawa: Instytut Spraw Publicznych; 2017 [cited 2018 Jan 12]. Avaliable from: https:/www.isp.org.pl/pl/publikacje/ adaptacja-miejsca-pracy-dla-starszych-i-niepelnosprawnychpracownikow-w-polsce.

62. Participation to Healthy Workplaces and Inclusive Strategies in the work Sector [Internet]. Brussels: The European project; 2016 [cited 2018 Jan 5]. Avaliable from: www.pathways.eu. 
63. Leonardi M, Scaratti C. Employment and People with Non Communicable Chronic Diseases: PATHWAYS Recommendations and Suggested Actions for Implementing an Inclusive Labour Market for All and Health in All Sectors. Int J Environ Res Public Health. 2018;15(8):1674, https://doi. org/10.3390/ijerph15081674.
64. Vlachou A, Stavroussi P, Roka O, Vasilou E, Papadimitriou D, Scaratti C, et al. Policy Guidelines for Effective Inclusion and Reintegration of People with Chronic Diseases in the Workplace: National and European Perspectives. Int J Environ Res Public Health. 2018;15(3):493, https://doi. org/10.3390/ijerph15030493.

This work is available in Open Access model and licensed under a Creative Commons Attribution-NonCommercial 3.0 Poland License - http://creativecommons.org/ licenses/by-nc/3.0/pl/deed.en. 